\title{
Simulating $\mathrm{N}_{2} \mathrm{O}$ fluxes from a Brazilian cropped soil with contrasted tillage practices
}

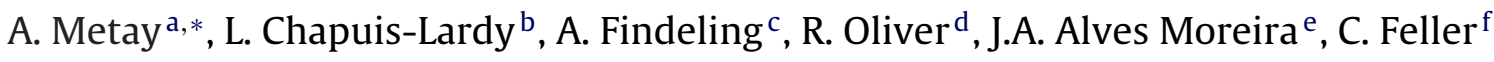 \\ a Montpellier Supagro, UMR SYSTEM (INRA-CIRAD-SupAgro), Bât. 27, 2 place Viala, 34060 Montpellier cedex 2, France \\ b IRD, UMR 210 EcoESSols, Bel Air, BP 1386, CP 18524 Dakar, Senegal \\ c CREED-Veolia, 291 Avenue Dreyfous Ducas - 78520 Limay, France \\ d CIRAD, UPR 78, avenue Agropolis 34394 Montpellier cedex 5, France \\ e EMBRAPA-CNPAF Rodovia Goiânia a Nova Veneza, km 12, Fazenda Capivara, C.P. 179 75375-000 Santo Antônio de Goiás, GO, Brazil \\ f IRD, UMR 210 EcoESols, Batiment 12, 2 place Viala, 34060 Montpellier cedex 2, France
}

\section{A R T I C L E I N F O}

\section{Article history:}

Received 25 August 2010

Received in revised form 9 December 2010

Accepted 9 December 2010

Available online 8 January 2011

\section{Keywords:}

$\mathrm{N}_{2} \mathrm{O}$ fluxes

Cropping systems

Tropical soils

Modelling

Denitrification

Nitrification

\begin{abstract}
A B S T R A C T
Assessing the $\mathrm{N}_{2} \mathrm{O}$ fluxes balance is a key challenge to estimate the effect of agriculture practices on greenhouse gas production. $\mathrm{N}_{2} \mathrm{O}$ fluxes remained difficult to measure on a field scale due to high spatial and temporal variability and usually low concentrations. Our work aimed at (i) characterizing by laboratory measurements soil potential $\mathrm{N}_{2} \mathrm{O}$ emissions from nitrification and denitrification and (ii) testing a modelling approach of $\mathrm{N}_{2} \mathrm{O}$ emissions that circumvents the problem of discrete measurements for two Brazilian rainfed rice cropping systems, no-tillage (NT) vs. disk tillage (DT). This latter approach consisted in the combination of 2 models: a mechanistic water transfer model and a $\mathrm{N}_{2} \mathrm{O}$ emission model, namely PASTIS and NOE. Simulations with the PASTIS + NOE approach showed for both NT and DT treatments that: (i) the soil emitted low amounts of $\mathrm{N}_{2} \mathrm{O}$, (ii) emissions by denitrification corresponded to short periods of high $\mathrm{N}_{2} \mathrm{O}$ emissions (15 times as high as emission by nitrification), (iii) nitrification contributed to ca $35 \%$ of the total $\mathrm{N}_{2} \mathrm{O}$ emissions at the crop cycle scale, (iv) field $\mathrm{N}_{2} \mathrm{O}$ emission measurements corresponded to the low bound of simulated emissions from nitrification.
\end{abstract}

(C) 2010 Elsevier B.V. All rights reserved.

\section{Introduction}

Although nitrous oxide $\left(\mathrm{N}_{2} \mathrm{O}\right)$ is only present as a trace gas in the atmosphere, it has 298 times the global warming potential of carbon dioxide $\left(\mathrm{CO}_{2}\right)$ and a lifespan of $\sim 120$ years (Crutzen, 1981). The continued increase of $\mathrm{N}_{2} \mathrm{O}$ in the atmosphere $(+18 \%$ since 1750; IPCC, 2007) is a serious environmental concern. However, the $\mathrm{N}_{2} \mathrm{O}$ budget is at present not well quantified, making it difficult to determine the sources and the cause of its increase precisely (IPCC, 2007). Agricultural soils contribute to about $60 \%$ of the global anthropogenic $\mathrm{N}_{2} \mathrm{O}$ flux (IPCC, 2007). $\mathrm{N}_{2} \mathrm{O}$ is produced during numerous nitrogen transformations in soils (Robertson and Tiedje, 1987), but on most occasions denitrification and nitrification are the main sources. The contribution of each process to $\mathrm{N}_{2} \mathrm{O}$ flux depends on climate, soil conditions characteristics and cropping systems. The number of published measurements of $\mathrm{N}_{2} \mathrm{O}$ fluxes from soils is increasing steadily at mid-latitudes (Europe and North America) but there are still few flux data from tropical and subtropical regions (Bouwman et al., 2002; Stehfest and Bouwman,

\footnotetext{
* Corresponding author. Tel.: +33 499612093; fax: +33 499613034

E-mail address: metay@supagro.inra.fr (A. Metay).
}

2006). The current IPCC methodology for producing national inventories of $\mathrm{N}_{2} \mathrm{O}$ from agricultural land provides a default emission factor (EF) of $1 \%$ of all $\mathrm{N}$ added to the soil (IPCC, 2007) while applying this mean value may overestimate the $\mathrm{N}_{2} \mathrm{O}$ flux for tropical agricultural soils (Chapuis-Lardy et al., 2009). In order to find the best constraints to the $\mathrm{N}_{2} \mathrm{O}$ budget, the representation of tropical agricultural systems in datasets really needs to be improved to provide additional information about driving factors of emissions. This will also allow an improvement of global $\mathrm{N}$-emission models and IPCC $\mathrm{N}_{2} \mathrm{O}$ flux factors.

Our field measurements in Brazil (Metay et al., 2007b) show high variability in time and space of $\mathrm{N}_{2} \mathrm{O}$ fluxes from soils as also reported by others in tropical (e.g. Chapuis-Lardy et al., 2009) and temperate (e.g. Yanai et al., 2003) systems. Ideally, the $\mathrm{N}_{2} \mathrm{O}$ fluxes should be extensively and continuously recorded at a field scale. Unfortunately, for practical reasons, most of the $\mathrm{N}_{2} \mathrm{O}$ studies are only based on a series of enclosed chamber measurements, and the uncertainty associated with up-scaling such discrete measurements to seasonal or annual budget estimates is often extremely large (Parkin, 2008). In the last fifteen years, the prediction of $\mathrm{N}_{2} \mathrm{O}$ fluxes within process-based agro-ecosystem models has emerged as a promising route to deal with these issues and improve the emission estimates (Cannavo et al., 2008; Chen et al., 
2008). They are based on the numerous soil and environmental factors controlling denitrification and nitrification such as soil moisture, soil temperature, and ammonium and/or nitrate contents. Amongst those models, Hénault et al. (2005) elaborate in successive steps NOE (nitrous oxide emission), a semi-empirical sub-model simulating the production and reduction of $\mathrm{N}_{2} \mathrm{O}$ in agricultural soils through both the denitrification and nitrification pathways. The denitrification component is derived from the NEMIS model (Hénault and Germon, 2000). Although NOE was developed for temperate soil and climate and validated on temperate datasets, its use was promising for tropical conditions (Hénault et al., 2005; Hergoualc'h et al., 2009). NOE parameterization required laboratory determination of site-specific biological activities, characterizing the nitrification and denitrification processes.

These $\mathrm{N}_{2} \mathrm{O}$-emitting processes also depend on the water-filled pore space (WFPS) in soils which is an indirect measure for the degree of soil aeration (Freney et al., 1978; Davidson, 1991; Bandibas et al., 1994). Soil moisture dynamics were satisfactorily simulated in tropical soils by PASTIS (predicting agriculture solute transport in soils; Lafolie, 1991), a mechanistic water transfer model (Reyes, 2002; Hergoualc'h et al., 2009). Here, we also used PASTIS to rebuild a 1-h time step estimation of soil water content from discrete measurements, over the whole cropping cycle. This estimate was introduced in the NOE model as the input data in replacement of daily soil water content measurements.

Our approach described the combined use of PASTIS and NOE models to simulate $\mathrm{N}_{2} \mathrm{O}$ fluxes from a tropical cropped soil. In situ $\mathrm{N}_{2} \mathrm{O}$ fluxes and detailed data necessary for the parameterization of these models were collected from tilled and no-till soils in the Cerrado region (Central Brazil). The area under no-till (NT) in Brazil reached 18 million ha, with a large part in the Cerrado (Bernoux et al., 2006). The aim is to explore how this model approach can be applied to better predict $\mathrm{N}_{2} \mathrm{O}$ fluxes from the no-till systems developed in Brazil.

\section{Material and methods}

\subsection{Site description}

The study area was located at the CNPAF (Centro Nacional de Pesquisa sobre Arroz e Feijão) research center near the city of Goiânia, Goiás state, $\operatorname{Brazil}\left(16^{\circ} 37^{\prime} \mathrm{S}, 49^{\circ} 13^{\prime} \mathrm{W}\right)$. Local natural vegetation is a tree savannah, the Cerrado, which gave its name to the region. The climate was tropical with a humid season from October to March and a dry season from April to September. The mean annual air temperature was $22.5^{\circ} \mathrm{C}$ and the mean annual precipitation was $1500 \mathrm{~mm}$. The soil was a clayey Oxisol (Soil Survey Staff, 1999) (latosolo vermelho escuro distrofico according to the Brazilian classification), with clay content around $40 \%$ in the upper layer. Topsoil organic carbon and total nitrogen contents were $16.4 \mathrm{mg} \mathrm{Cg}^{-1}$ soil and $1.1 \mathrm{mg} \mathrm{N} \mathrm{g}^{-1}$ soil respectively. Soil fractionation (Metay et al., 2007a) showed low amounts of aggregates with a size $>2 \mathrm{~mm}$. This soil had a low cation exchange capacity $\left(3.3 \mathrm{cmol}(+) \mathrm{kg}^{-1}\right)$, dominated by exchangeable $\mathrm{Ca}$, and a $\mathrm{pH}$ (in water) of 6.0 .

The subsurface horizon of these soils has a weak pulverized structure known as "coffee powder" (EMBRAPA, 1984) with a uniform macropore distribution (Van den Berg et al., 1997). Even if the structural stability is higher in the surface horizon, its porosity distribution remains uniform (Castro and Logan, 1991).

\subsection{Experimental design}

The experimental design was established in the station in 1998 on a 6 ha field and consisted in randomised blocks of rainfed rice-soyabean rotation conducted with or without tillage (Metay et al., 2007a,b). Our present study focused on four plots sown with rice (Oryza sativa) with previous crop (soyabean) residues left on the soil after harvest. In no-till (NT) treatment, the leguminous Crotalaria spectabilis was sown to cover the soil after rice harvest. NT plots were treated before planting with paraquat and glyphosate as needed for weed control (Metay et al., 2007a). Tillage (DT) was practised in other plots with an offset disc harrow at $15 \mathrm{~cm}$ depth. Mineral N fertilization, in both NT and DT treatments, consisted of ammonium sulphate $\left(100 \mathrm{~kg} \mathrm{ha}^{-1}\right)$ immediately after seeding and urea $\left(100 \mathrm{~kg} \mathrm{ha}^{-1}\right) 2$ weeks and 6 weeks after seeding. The P and $\mathrm{K}$ fertilization (in supertriple phosphate and potassium chloride forms) corresponded to $52.8 \mathrm{~kg} \mathrm{Pha}^{-1}$ and $49.8 \mathrm{~kg} \mathrm{~K} \mathrm{ha}^{-1}$ respectively. Soil bulk densities were 1.26 and $1.24 \mathrm{~g} \mathrm{~cm}^{-3}$ in NT and DT treatments respectively.

\subsection{In situ $\mathrm{N}_{2} \mathrm{O}$ fluxes and ancillary soil properties}

Soil $\mathrm{N}_{2} \mathrm{O}$ fluxes from Metay et al. (2007b) were measured from static chambers at key periods as recommended in literature (Baggs et al., 2003; Davidson et al., 1996; Dick et al., 2001; Smith et al., 2003): (i) during the rainy season (November to March) that is the most relevant period to measure $\mathrm{N}_{2} \mathrm{O}$ fluxes under tropical conditions, (ii) during the first days after $\mathrm{N}$-fertilizer application (December and January), and (iii) during the first stages of cover residue decomposition (from grass or legumes) (November) that are both favourable to $\mathrm{N}_{2} \mathrm{O}$ fluxes. Three times a week, during the morning, gas samples were taken using a gas-tight syringe in 6 chambers per plot at chamber closure and 10, 30, 60 and $120 \mathrm{~min}$ after closure. Gas samples were stored in $13 \mathrm{~mL}$ vacutainer ${ }^{\circledR}$ tubes which were previously purged and analyzed for $\mathrm{N}_{2} \mathrm{O}$ by gas chromatography (Varian $3800,3 \mathrm{~m}$ Porapak Q column, vector gas $\mathrm{N}_{2}$ ) within one month after collection. Hourly fluxes were calculated from the linear increase in gas concentration in the chamber headspace with time according to Metay et al. (2007b) after being tested for nonlinearity.

Soil temperature was recorded with a digital thermometer at $5 \mathrm{~cm}$ depth and a topsoil $(0-10 \mathrm{~cm}$ depth) composite sample was collected on each $\mathrm{N}_{2} \mathrm{O}$ flux measurement date. Soil mineral ammonium $\left(\mathrm{NH}_{4}^{+}\right)$and nitrate $\left(\mathrm{NO}_{3}{ }^{-}\right)$contents were determined after soil extraction in $1 \mathrm{M} \mathrm{KCl}$ on a continuous flow colorimeter (Alliance ${ }^{\circledR}$ Integral Futura equipment) using a cadmium reduction to nitrite and Griess reagent for $\mathrm{NO}_{3}{ }^{-}$and Berthelot reaction for $\mathrm{NH}_{4}{ }^{+}$, as described by Mulvaney (1996). Soil moisture was determined gravimetrically by drying intact soil core samples at $105^{\circ} \mathrm{C}$ during $48 \mathrm{~h}$ in order to calculate water filled pore space (WFPS) (Linn and Doran, 1984).

\subsection{Soil moisture simulation using the PASTIS model}

Soil moisture has a large influence on $\mathrm{N}_{2} \mathrm{O}$ fluxes through its impact on the volume of soil in which denitrification occurs and the duration of denitrifying conditions. The monodimensional mechanistic model PASTIS (Lafolie, 1991) was used to simulate the water transfer in the soil during plant growth in the presence of surface mulch when appropriate (Findeling, 2001) for both NT and DT treatments. The model provides for each time step the soil water content on a vertical profile of soil structured in homogeneous horizontal layers $(0-10 \mathrm{~cm}$ and $10-30 \mathrm{~cm})$. Boundary conditions for heat and water flows were taken from Reyes (2002) who worked in related systems in the study area. Initial conditions derived from a soil water content profile which was measured at the beginning of the rainy season. The calibration was carried out by slightly tuning soil hydraulic properties (Table 1 ). We finally checked parameter consistency by comparison with the range obtained by Reyes (2002). 
Table 1

Soil hydraulic properties parameterizing the PASTIS (prediction of agricultural solute transfer in mulch soils) model in no-till (NT) and tillage (DT) treatments.

\begin{tabular}{|c|c|c|c|c|}
\hline & \multicolumn{2}{|l|}{ NT } & \multicolumn{2}{|l|}{ DT } \\
\hline & $0-10$ & $10-30$ & $0-10$ & $10-30$ \\
\hline Soil saturation volumetric water content, $\theta_{\mathrm{s}}\left(\mathrm{m}^{3} \mathrm{~m}^{-3}\right)$ & 0.50 & 0.41 & 0.45 & 0.43 \\
\hline Soil residual volumetric water content, $\theta_{\mathrm{r}}\left(\mathrm{m}^{3} \mathrm{~m}^{-3}\right)$ & 0.156 & 0.180 & 0.160 & 0.180 \\
\hline Saturated soil hydraulic conductivity, $K_{\text {sat }}\left(10^{-4} \mathrm{~m} \mathrm{~s}^{-1}\right)$ & 28.3 & 3.1 & 17.7 & 3.1 \\
\hline
\end{tabular}

0-10 and 10-30 indicate soil depth (cm).

\section{5. $\mathrm{N}_{2} \mathrm{O}$ flux simulation using the NOE model}

NOE (Hénault et al., 2005) is an algorithm to predict $\mathrm{N}_{2} \mathrm{O}$ fluxes from soil (Table 2). NOE model was used to simulate $\mathrm{N}_{2} \mathrm{O}$ flux on the whole cropping cycle in 2002-2003 which also corresponded to the rainy season (November 15 th-March 5 th), particularly favourable to $\mathrm{N}_{2} \mathrm{O}$ fluxes. Total $\mathrm{N}_{2} \mathrm{O}$ flux from the soil simulated by NOE was the sum of the $\mathrm{N}_{2} \mathrm{O}$ fluxes produced by denitrification $\left(\mathrm{N}_{2} \mathrm{O}\right.$ denit) and by nitrification $\left(\mathrm{N}_{2} \mathrm{O}\right.$ nit).

The $\mathrm{N}_{2} \mathrm{O}$ denit $\left(\mathrm{kg} \mathrm{N}-\mathrm{N}_{2} \mathrm{Oha}^{-1} \mathrm{~d}^{-1}\right)$ is calculated according to Garrido et al. (2002):

$\mathrm{N}_{2} \mathrm{O}$ denit $=r_{\max } D_{\mathrm{A}}$

where $D_{\mathrm{A}}\left(\mathrm{kg} \mathrm{N} \mathrm{ha}^{-1} \mathrm{~d}^{-1}\right)$ is the actual denitrification rate, and $r_{\max }$ (dimensionless) is the maximum ratio of accumulated emitted $\mathrm{N}_{2} \mathrm{O}$ and denitrified $\mathrm{NO}_{3}{ }^{-}$under anaerobic condition (Hénault et al., 2001). $D_{\mathrm{A}}$ is defined by a multiplicative function of potential denitrification rate and dimensionless functions of soil $\mathrm{NO}_{3}{ }^{-}$content, WFPS and temperature (Hénault and Germon, 2000):

$D_{\mathrm{A}}=D_{\mathrm{P}} F_{\mathrm{N}} F_{\mathrm{T}} F_{\mathrm{W}}$

where $D_{\mathrm{P}}\left(\mathrm{kg} \mathrm{Nha}^{-1} \mathrm{~d}^{-1}\right)$ is the potential denitrification rate, $F_{\mathrm{N}}$, $F_{\mathrm{T}}$ and $F_{\mathrm{W}}$ are the response factors to soil nitrate, soil temperature and water-filled pore space (WFPS), respectively. The process of denitrification is highly sensitive to WFPS and starts to occur above

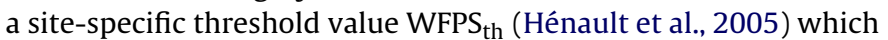

determination was detailed at a later point in this methodology section.

The NOE model considers that in denitrifying conditions, $\mathrm{N}_{2} \mathrm{O}$ produced by nitrification is denitrified at the same rate $\left(r_{\max }\right)$ that $\mathrm{N}_{2} \mathrm{O}$ produced by denitrification. Nitrification is also known to be inhibited in aeration-limited conditions (Mosier et al., 1998). Nitrous oxide produced by nitrification $\left(\mathrm{N}_{2} \mathrm{O}\right.$ nit; $\mathrm{kg} \mathrm{N}$ $\mathrm{N}_{2} \mathrm{O} \mathrm{ha}^{-1} \mathrm{~d}^{-1}$ ) is calculated as:

$\mathrm{N}_{2} \mathrm{O}$ nit $=z N_{\mathrm{A}}$ when WFPS $<$ WFPS $_{\text {th }}$

$\mathrm{N}_{2} \mathrm{O}$ nit $=r_{\max } z N_{\mathrm{A}}$ when WFPS $=$ WFPS $_{\text {th }}$

where $z$ (dimensionless) is the proportion of nitrified nitrogen emitted as $\mathrm{N}_{2} \mathrm{O}$ (Garrido et al., 2002), and $N_{\mathrm{A}}\left(\mathrm{kg} \mathrm{N} \mathrm{ha}^{-1} \mathrm{~d}^{-1}\right)$ is the actual nitrification rate (Hénault et al., 2005). The nitrification rate is calculated as follows:

$N_{\mathrm{A}}=N_{\mathrm{W}} N_{\mathrm{NH}_{4}} N_{\mathrm{T}}$

where $N_{\mathrm{W}}\left(\mathrm{kg} \mathrm{Nha}^{-1} \mathrm{~d}^{-1}\right), N_{\mathrm{NH}_{4}}, N_{\mathrm{T}}$ are the response functions to soil water content, soil ammonium content and soil temperature (Hénault et al., 2005). $N_{\mathrm{W}}$ is assumed to be a linear function of soil water content:

$N_{\mathrm{W}}=a \mathrm{WC}+b$

where WC $\left(\mathrm{kg} \mathrm{kg}^{-1}\right)$ is soil gravimetric water content, $a$ and $b$ ( $\mathrm{kg}$ $\mathrm{N} \mathrm{ha}^{-1} \mathrm{~d}^{-1}$ ) are soil-specific parameters (Garrido et al., 2002).

Table 2

List of parameters used in NOE model - definition and method for determination.

\begin{tabular}{|c|c|c|c|c|}
\hline Parameter & Definition & Dimension & $\begin{array}{l}\text { Determination (calculation or } \\
\text { laboratory) }\end{array}$ & References \\
\hline$D_{\mathrm{P}}$ & Potential denitrification rate & $\mathrm{kg} \mathrm{Nha}^{-1} \mathrm{~d}^{-1}$ & Laboratory determination & Hénault and Germon, 2000 \\
\hline$F_{\mathrm{N}}$ & $\begin{array}{l}\text { Denitrification response factor to soil } \\
\mathrm{NO}_{3}^{-} \text {content }\end{array}$ & Dimensionless & $\begin{array}{l}F_{\mathrm{N}}=\frac{\left[\mathrm{NO}_{3}^{-}\right]}{\mathrm{Km} 1+\left[\mathrm{NO}_{3}^{-}\right]} \text {with }\left[\mathrm{NO}_{3}{ }^{-}\right] \text {derived } \\
\text { from field data collection and } \mathrm{Km} 1 \\
\text { constant equal to } 22 \mathrm{mg} \mathrm{N}-\mathrm{NO}_{3}^{-} \mathrm{kg}^{-1} \\
\text { soil }\end{array}$ & Hénault and Germon, 2000 \\
\hline$F_{\mathrm{T}}$ & $\begin{array}{l}\text { Denitrification response factor soil } \\
\text { temperature }(T)\end{array}$ & Dimensionless & $\begin{array}{l}F_{\mathrm{T}}=\exp \left[\frac{(T-11) \ln (89)-9 \ln (2.1)}{10}\right], \text { if } \\
T<11^{\circ} \mathrm{C} F_{\mathrm{T}}=\exp \left[\frac{(T-20) \ln (2.1)}{10}\right], \text { if } \\
T \geq 11^{\circ} \mathrm{C}, \text { calculated from field data } \\
\text { collection }\end{array}$ & Hénault and Germon, 2000 \\
\hline$F_{\mathrm{w}}$ & $\begin{array}{l}\text { Denitrification response factor to } \\
\text { water-filled pore space (WFPS) }\end{array}$ & Dimensionless & $\begin{array}{l}F_{\mathrm{W}}=\left[\frac{\mathrm{WFPS}-0.7}{0.3}\right]^{\mathrm{BD}} \text { with BD: bulk } \\
\text { density determined from field data and } \\
\text { WFPS (water-filled pore space) } \\
\text { calculated from field data or water } \\
\text { content simulation using PASTIS model }\end{array}$ & Hénault and Germon, 2000 \\
\hline$z$ & $\begin{array}{l}\text { Proportion of nitrified nitrogen } \\
\text { emitted as } \mathrm{N}_{2} \mathrm{O}\end{array}$ & Dimensionless & Laboratory determination & Garrido et al., 2002 \\
\hline$N_{\mathrm{w}}$ & $\begin{array}{l}\text { Nitrification response function to } \\
\text { gravimetric soil water content (WC) }\end{array}$ & $\mathrm{kg} \mathrm{Nha}^{-1} \mathrm{~d}^{-1}$ & $\begin{array}{l}N_{\mathrm{w}}=a \mathrm{WC}+b \text { from laboratory } \\
\text { determination }\end{array}$ & Garrido et al., 2002 \\
\hline$N_{\mathrm{NH}_{4}}+$ & $\begin{array}{l}\text { Nitrification response function to } \mathrm{NH}_{4}{ }^{+} \\
\text {content }\end{array}$ & Dimensionless & $\begin{array}{l}N_{\mathrm{NH}_{4}}=\frac{\left[\mathrm{NH}_{4}^{+}\right]}{\mathrm{Km} 2^{+}+\left[\mathrm{NH}_{4}^{+}\right]} \text {with }\left[\mathrm{NH}_{4}^{+}\right] \\
\text {determined from field data and } \mathrm{Km} 2 \\
\text { constant equal to } 2.6 \mathrm{mg} \mathrm{N}-\mathrm{NH}_{4}^{+} \mathrm{kg}^{-1} \\
\text { soil }\end{array}$ & Hénault et al., 2005 \\
\hline$N_{\mathrm{T}}$ & $\begin{array}{l}\text { Nitrification response function to } \\
\text { temperature }\end{array}$ & Dimensionless & Equal to $F_{\mathrm{T}}$ & Hénault et al., 2005 \\
\hline$r_{\max }$ & $\begin{array}{l}\text { Maximum ratio of accumulated } \mathrm{N}_{2} \mathrm{O} \text { to } \\
\text { denitrified } \mathrm{NO}_{3}{ }^{-} \text {under anaerobic } \\
\text { incubations }\end{array}$ & Dimensionless & Anaerobic incubation & Garrido et al., 2002 \\
\hline
\end{tabular}


While $F_{\mathrm{N}}, N_{\mathrm{NH}_{4}}, F_{\mathrm{T}}$ and $N_{\mathrm{T}}$ were derived from data field collection (soil $\mathrm{NO}_{3}{ }^{-}, \mathrm{NH}_{4}{ }^{+}$contents; soil temperature measured three times a week for all treatments), WFPS and $F_{\mathrm{W}}$ were obtained using onfield measurements (bulk density, soil gravimetric water content) and soil moisture as simulated by PASTIS. The biological parameters required by $\operatorname{NOE}\left(D_{\mathrm{P}}, r_{\max }, a, b, z\right)$ were obtained in laboratory incubations as described in Section 2.6. The NOE model was used to simulate the soil $\mathrm{N}_{2} \mathrm{O}$ fluxes during a crop cycle in the rainy season, from November to March.

\subsection{Laboratory determination of biological parameters required by NOE}

\subsubsection{Soil collection for laboratory determination}

For both denitrification and nitrification determinations, composite soil samples were formed by pooling sub-samples randomly collected near each chamber at the end of the cropping season in both treatments to ensure at least the representativeness of the spatial soil heterogeneity under a chamber $\left(0.08 \mathrm{~m}^{2}\right)$. Based on the $\mathrm{N}_{2} \mathrm{O}$ soil profiles reported by Metay et al. (2007b) for this experimental design, the soil was sampled in the surface layers. Composite soil samples were sieved through $2-\mathrm{mm}$ mesh and stored at $4{ }^{\circ} \mathrm{C}$ before incubation

\subsubsection{Potential denitrification rate $\left(D_{P}\right)$ and the proportion of denitrified $\mathrm{N}$ emitted as $\mathrm{N}_{2} \mathrm{O}\left(r_{\max }\right)$}

The capacities for production and reduction of $\mathrm{N}_{2} \mathrm{O}$ during denitrification were investigated in the laboratory according to Hénault et al. (2001). Three replicates of soil sample equivalent to $10 \mathrm{~g}$ of dry soil were placed in 125-ml flasks and put under anaerobic conditions by five successive cycles of vacuum-filling by helium. Two sets of incubation were carried out with the addition of $\mathrm{NO}_{3}{ }^{-}(38.25 \mu \mathrm{g}$ $\mathrm{Ng}^{-1}$ dry soil) as electron acceptor (1) in the presence of acetylene $\left(\mathrm{C}_{2} \mathrm{H}_{2} ; 10 \%\right.$ of the gas atmosphere) in order to determine $D_{\mathrm{P}}$, the potential denitrification rate, i.e. $\mathrm{N}_{2} \mathrm{O}$ and $\mathrm{N}_{2}$ normally produced by denitrification and (2) without the addition of acetylene in order to measure the potential production of $\mathrm{N}_{2} \mathrm{O}$ during denitrification. The difference between these two treatments was used to calculate the soil potential for $\mathrm{N}_{2} \mathrm{O}$ reduction. The flasks were maintained at $28^{\circ} \mathrm{C}$ during 8 days in the dark. An aliquot of the atmosphere in the flask was sampled after $1,2,3,6,8$ days of incubation $\left(t_{i}\right)$ for $\mathrm{N}_{2} \mathrm{O}$ analysis on a gas chromatographer equipped with an electron capture detector (Varian 3800).

The proportion of denitrified $\mathrm{N}$ emitted as $\mathrm{N}_{2} \mathrm{O}$ is defined as:

$r_{\max }=\max \left(\frac{\mathrm{N}_{2} \mathrm{O}_{0 \mathrm{C}_{2} \mathrm{H}_{2}}}{\mathrm{~N}_{2} \mathrm{O}_{10 \% \mathrm{C}_{2} \mathrm{H}_{2}}}\right)_{t_{i}}$

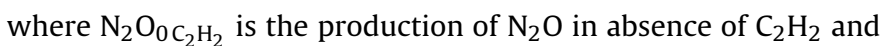

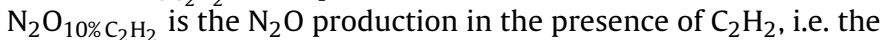
total gaseous $\mathrm{N}$ production $\left(\mathrm{N}_{2} \mathrm{O}+\mathrm{N}_{2}\right.$ ) (Hénault et al., 2001). Since denitrification, as a heterotrophic process, is dependent on organic $\mathrm{C}$ supply, the $\mathrm{CO}_{2}$ released during incubations was also monitored to assess concomitant respiration rates and control that organic carbon was not a limiting factor. Measurement of $\mathrm{NH}_{4}{ }^{+}$and $\mathrm{NO}_{3}{ }^{-}$ in soil samples was performed after $\mathrm{KCl}$ extraction at the end of the incubation.

\subsubsection{Determination of the WFPS threshold for $\mathrm{N}_{2} \mathrm{O}$ production by denitrification}

As the water filled pore space increases, diffusion of oxygen into soil will decrease, and a rapidly increasing fraction of the soil volume will become anaerobic, causing increased $\mathrm{N}_{2} \mathrm{O}$ production by denitrification (Dobbie and Smith, 2003). The NOE model uses a soil moisture threshold value $\left(\mathrm{WFPS}_{\mathrm{th}}\right)$ to switch on/off denitrification. Soil samples were incubated in the laboratory at five WFPS lev- els (37, 50, 60, 70 and 80\%) following WFPS adjustment procedure as described by Hergoualc'h et al. (2007). Eighty grams of dry soil were placed in plastic cylinders $(8 \mathrm{~cm}$ in diameter $)$, mixed with a solution of $\mathrm{KNO}_{3}$ with $1.15 \mathrm{~g} \mathrm{~N} \mathrm{~L}^{-1}$, and packed to simulate the bulk density observed on field for each treatment (NT and DT). Distilled water was added to reach the specific WFPS values. The cylinders were incubated in airtight glass flasks at $28^{\circ} \mathrm{C}$ in the dark during four days. The atmosphere in the flasks was sampled daily and analyzed for $\mathrm{N}_{2} \mathrm{O}$ by gas chromatography. Mineral $\mathrm{N}$ content $\left(\mathrm{NH}_{4}{ }^{+}\right.$and $\mathrm{NO}_{3}{ }^{-}$) were determined in $\mathrm{KCl}$ extracts of soil samples by methods previously described.

\subsection{4. $\mathrm{N}_{2} \mathrm{O}$ production by nitrification as a function of WFPS}

The methodology used was to determine how soil moisture influenced the production of $\mathrm{N}_{2} \mathrm{O}$ by nitrification adapted from Garrido et al. (2002). Soil sample equivalent to $10 \mathrm{~g}$ of dry soil were placed in 125-ml airtight glass flasks, packed to simulate the bulk density observed on field and incubated in the laboratory at five WFPS values $(20,26,32,37,46 \%)$. Non-limiting $\mathrm{NH}_{4}{ }^{+}$conditions were provided by addition of ammonium sulphate $\left(0.4 \mathrm{mg} \mathrm{N} \mathrm{g}^{-1}\right.$ dry soil) at the same time as water to adjust soil moisture to the appropriate WFPS level. Flasks were incubated for 9 days at $28^{\circ} \mathrm{C}$ in the dark. Soil moisture was regularly checked and adjusted during at the incubation period and no significant evolution was observed. Each treatment is repeated three times. $\mathrm{N}_{2} \mathrm{O}$ concentrations were measured in the flask atmosphere while measurements of $\mathrm{NH}_{4}{ }^{+}$ and $\mathrm{NO}_{3}{ }^{-}$were performed in $\mathrm{KCl}$ extracts of soil, both with previously described methods and instrumentation. An additional series of 36 samples is placed in flask serums of $125 \mathrm{ml}$ to determine potential nitrate losses at the end of the incubation. The nitrification rates were determined as the soil nitrate production. The $z$ parameter in Eqs. (3) and (4) was the proportion of nitrified $\mathrm{N}$ emitted as $\mathrm{N}_{2} \mathrm{O}$, and $a$ and $b$ values in Eq. (6) were the slope and the $Y$-intercept, respectively, of the linear relationship between soil nitrification rate and soil moisture (Garrido et al., 2002).

\subsection{Statistics}

Data are presented as mean values with standard deviation. Data were analyzed using XLSTAT software (AddinSoft). Student's unpaired $t$-test was applied to identify significant differences between data set at a 0.05 probability level. The PASTIS and NOE simulations were compared with field observations using graphics to capture dynamic trends. We used an efficiency criterion (EFF) based on the comparison of simulated and measured soil water contents for the different studied layers (Nash and Sutcliffe, 1970) to estimate PASTIS model performance:

$\mathrm{EFF}=1-\frac{\sum_{i}^{n}\left(x_{\text {sim }, i}-x_{\text {mes }, i}\right)^{2}}{\sum_{i}^{n}\left(\bar{x}_{\text {moy }}-x_{\text {mes }, i}\right)^{2}}$

with $x_{\text {sim }, i}, i$ simulation of soil water content; $x_{\text {mes, } i}, i$ measurement of soil water content; $\bar{x}_{\text {moy }}$, mean of the $x_{\text {mes, } i}$.

\section{Results}

\subsection{Parameters in NOE model}

\subsubsection{Potential denitrification rate $\left(D_{P}\right)$ and the proportion of} denitrified $\mathrm{N}$ emitted as $\mathrm{N}_{2} \mathrm{O}\left(r_{\max }\right)$

The potential denitrification rate $\left(D_{\mathrm{P}}\right)$ was around $1 \mathrm{~kg} \mathrm{~N}$ $\mathrm{N}_{2} \mathrm{Oha}^{-1} \mathrm{~d}^{-1}$ with a slightly higher value for tilled (DT) than for no-tilled (NT) treatments (1.072 vs. $0.987 \mathrm{~kg} \mathrm{~N}-\mathrm{N}_{2} \mathrm{O} \mathrm{ha}^{-1} \mathrm{~d}^{-1}$ respectively) (Table 3 ). The $\mathrm{N}_{2} \mathrm{O}$ production in anaerobic conditions in the presence or absence of $\mathrm{C}_{2} \mathrm{H}_{2}$ was monitored over 10 days but the reduction of $\mathrm{N}_{2} \mathrm{O}$ to $\mathrm{N}_{2}$ was only observed after 6 days 
Table 3

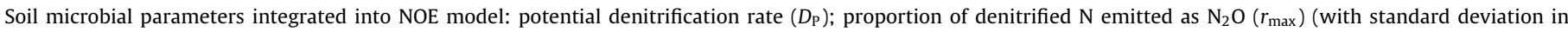

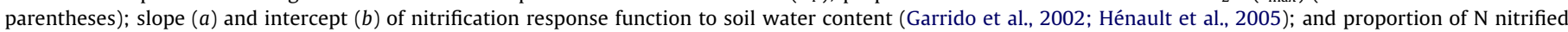
emitted as $\mathrm{N}_{2} \mathrm{O}(z)$.

\begin{tabular}{|c|c|c|c|}
\hline Parameters & Symbol (unit) & NT & DT \\
\hline Potential denitrification rate & $D_{\mathrm{P}}\left(\mathrm{kg} \mathrm{Nha}^{-1} \mathrm{~d}^{-1}\right)$ & $1.072(0.004)$ & $0.987(0.035)$ \\
\hline Proportion of denitrified $\mathrm{N}$ emitted as $\mathrm{N}_{2} \mathrm{O}$ & $r_{\max }$ & 0.48 & 0.59 \\
\hline Slope of nitrification response function to soil water content & $a\left(\mathrm{~kg} \mathrm{Nha}^{-1} \mathrm{~d}^{-1}\right)$ & 0.15 & 0.06 \\
\hline Intercept of nitrification response function to soil water content & $b\left(\mathrm{~kg} \mathrm{Nha}^{-1} \mathrm{~d}^{-1}\right)$ & -1.66 & -0.66 \\
\hline Proportion of $\mathrm{N}$ nitrified emitted as $\mathrm{N}_{2} \mathrm{O}$ & $z$ & 0.0003 & 0.00044 \\
\hline
\end{tabular}

(data not shown). The proportion of denitrified $\mathrm{N}$ emitted as $\mathrm{N}_{2} \mathrm{O}$ $\left(r_{\max }\right)$ was slightly higher for DT than for NT treatments (0.59 vs. 0.48 respectively) (Table 3 ).

\subsubsection{WFPS threshold for $\mathrm{N}_{2} \mathrm{O}$ production by denitrification}

Fig. 1 shows the shape of the response of denitrification to WFPS in non-limiting $\mathrm{N}$ conditions. $\mathrm{N}_{2} \mathrm{O}$ was not substantially emitted

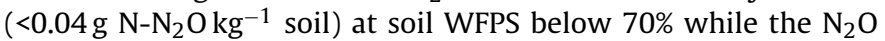
production reached values up to 58 times higher at 80\% WFPS (from 0.2 to 1.0 and from 0.4 to $2.1 \mathrm{~g} \mathrm{~N}-\mathrm{N}_{2} \mathrm{O} \mathrm{kg}^{-1}$ soil in DT and NT, respectively). It is worth noting that at this WFPS level (80\%), $\mathrm{N}_{2} \mathrm{O}$ fluxes from NT were significantly higher than those from DT soils. The WFPS threshold beyond which denitrification may occur is $70 \%$ in the studied soil. The WFPS $_{\text {th }}$ parameter in NOE model might be raised from 0.62 (default value) to 0.70 .

\subsubsection{Nitrification kinetics}

The rates of nitrification were calculated, for each WFPS level, from the nitrate accumulation during 9-d soil incubation. Soil nitrification rates increased along with soil moisture from 0.21 to $2.16 \mathrm{mg} \mathrm{N}-\mathrm{NO}_{3}{ }^{-} \mathrm{kg}^{-1}$ soild ${ }^{-1}$ in NT and 0.10 to $0.92 \mathrm{mg} \mathrm{N}-$ $\mathrm{NO}_{3}{ }^{-} \mathrm{kg}^{-1}$ soil d ${ }^{-1}$ in DT treatments, respectively (Table 4 ). The nitrification parameters entering NOE model, i.e. the slope (a) and the intercept $(b)$ of the linear relationship between soil nitrification rate and soil moisture were presented in Table 3 . The proportion of nitrified $\mathrm{N}$ emitted as $\mathrm{N}_{2} \mathrm{O}(z)$ was lower in no-till (NT) compared to tillage (DT) treatment (0.00030 vs. 0.00044 , respectively; Table 3$)$.

\subsection{Simulation of soil water content using PASTIS}

The PASTIS model simulated satisfactorily the soil water content for both treatments at $0-10 \mathrm{~cm}$ (Fig. 2) and $10-30 \mathrm{~cm}$ (data not

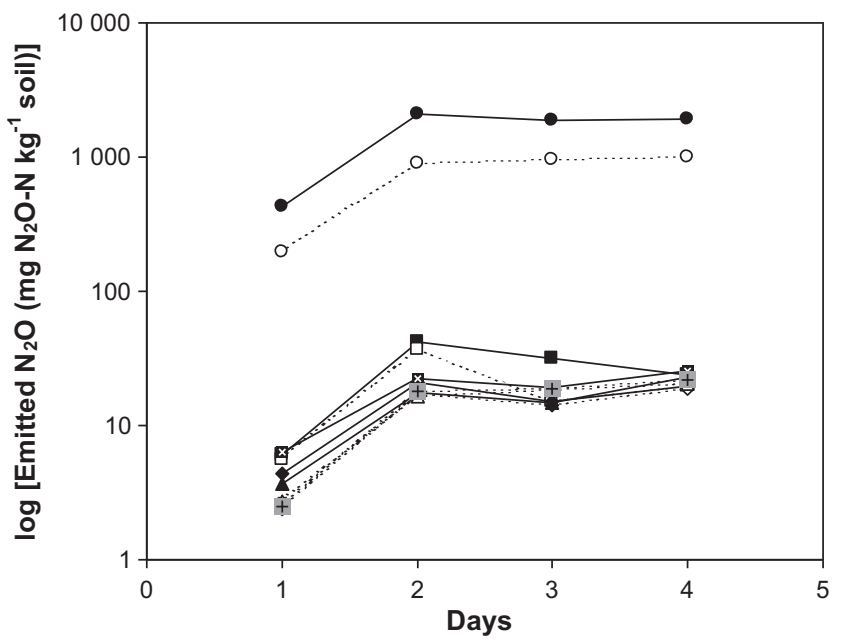

Fig. 1. $\mathrm{N}_{2} \mathrm{O}$ production ( $\mathrm{mg} \mathrm{N}_{2} \mathrm{O}-\mathrm{N} \mathrm{kg}^{-1}$ soil) from NT (black shapes; solid lines) and DT (white shapes; dashed lines) soils incubated in non-limiting $\mathrm{N}$ conditions at different WFPS levels (37\%: square, $50 \%$ : diamond, $60 \%$ : triangle, $70 \%$ : shaped cross, $80 \%$ : circle). Note the log scale on the $y$ axis.
Table 4

Nitrification rates $\left(N_{\mathrm{w}}\right)$ for NT (no-till) and DT (disc-tilled) soils.

\begin{tabular}{lll}
\hline WFPS (\%) & \multicolumn{2}{l}{$N_{\mathrm{w}}\left(\mathrm{mg} \mathrm{N}^{\left.-\mathrm{NO}_{3}{ }^{-} \mathrm{kg}^{-1} \mathrm{soil} \mathrm{d}^{-1}\right)}\right.$} \\
\cline { 2 - 3 } & $\mathrm{NT}$ & $\mathrm{DT}$ \\
\hline 20 & $0.21(0.07) \mathrm{a}$ & $0.10(0.04) \mathrm{b}$ \\
26 & $0.70(0.05) \mathrm{c}$ & $0.39(0.02) \mathrm{d}$ \\
32 & $1.22(0.12) \mathrm{e}$ & $0.42(0.04) \mathrm{d}$ \\
37 & $1.68(0.10) \mathrm{f}$ & $0.76(0.05) \mathrm{c}$ \\
46 & $2.16(0.24) \mathrm{g}$ & $0.92(0.03) \mathrm{h}$ \\
\hline
\end{tabular}

Nitrification rates $\left(N_{\mathrm{w}}\right)$ of soils were determined after $\mathrm{NH}_{4}{ }^{+}$addition and incubation for 9 days at five levels of WFPS. NT: no-till, DT: disc-tilled soils. Mean (standard deviation, $n=3$ ). Different letters indicate statistical differences between data at a 0.05 probability level.

shown) soil depth. However some discrepancies were observed for the NT treatment where the presence of mulch reduced the model efficiency when simulated the water content in the $0-10$ soil layer $(E F F=0.67$ vs. 0.74 for NT and DT, respectively). Simulations highlighted for both treatments that the soil reached quite high water contents $\left(\sim 0.4 \mathrm{~m}^{3} \mathrm{~m}^{-3}\right)$, mainly after rainfall events, which were
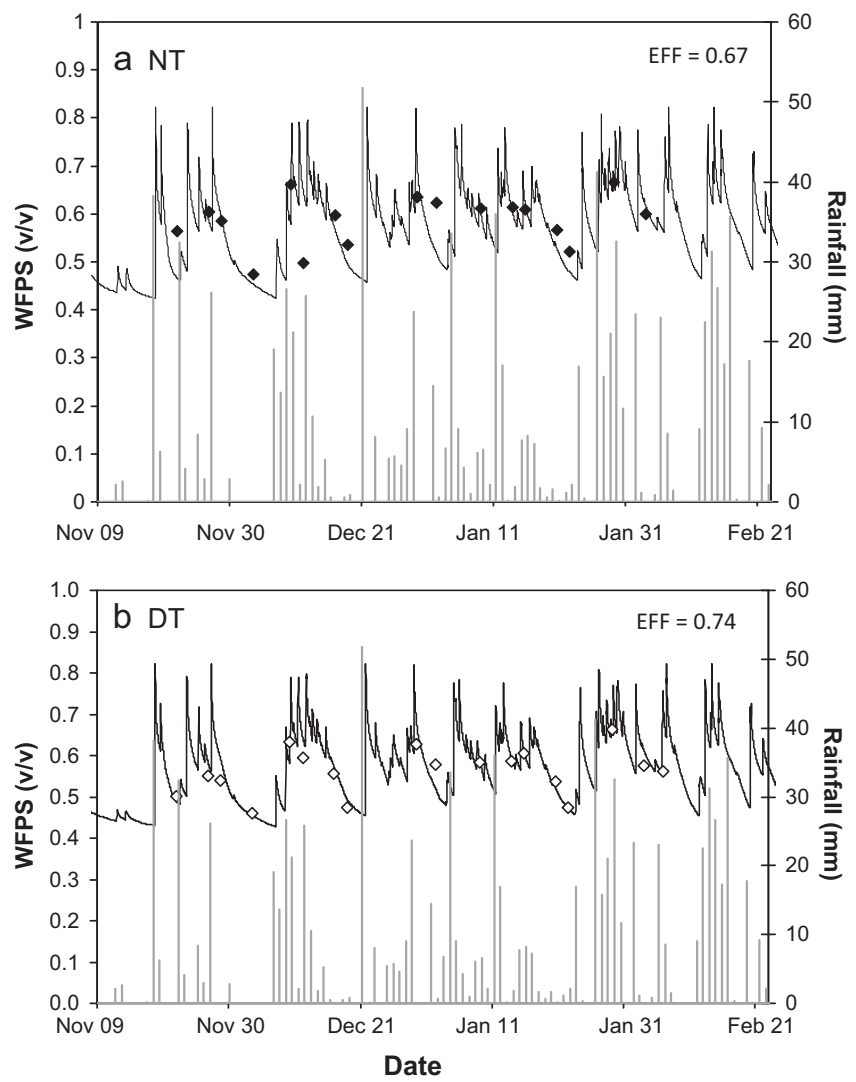

Fig. 2. Rainfall ( $\mathrm{mm}$ ) (grey vertical lines) and water-filled pore space (WFPS, v/v) of the $0-10 \mathrm{~cm}$ soil layer simulated (black line) and measured (diamonds) during the rainy season in the (a) no-till (NT) and (b) tillage (DT) treatments. EFF: model efficiency. 

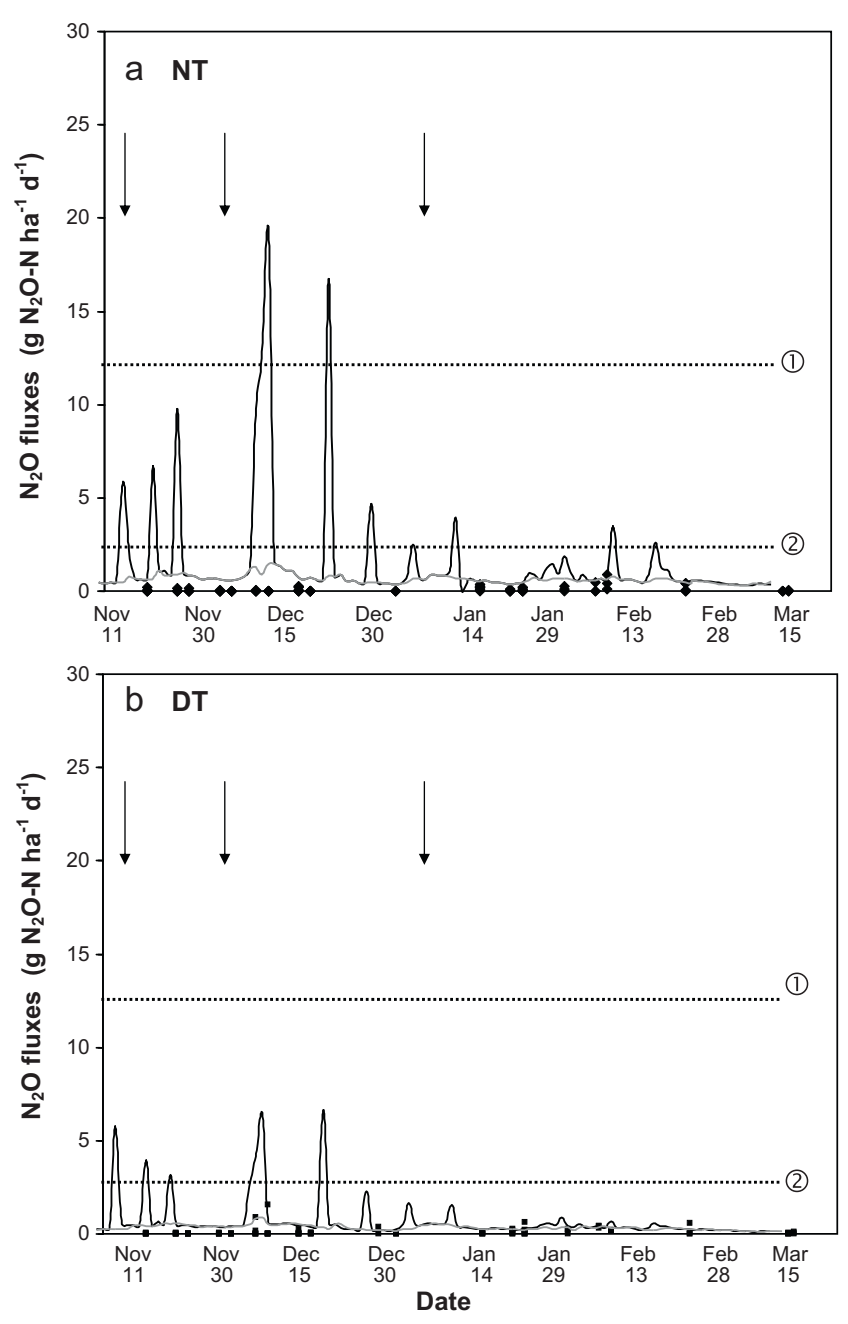

Fig. 3. Soil $\mathrm{N}_{2} \mathrm{O}$ fluxes simulated with nitrification function only (grey line) and with both nitrification and denitrification (black line), and measured in no-till (black diamond) and tillage (black square) systems of Central Brazil. Each measurement represents the mean for 6 repetitions. The arrows indicate the fertilizer applications, and the horizontal dashed lines represent low (1) and very low (2) $\mathrm{N}_{2} \mathrm{O}$ emissions levels according to Scheer et al. (2008).

not captured by discrete measurements (Fig. 2). The simulated soil water content was introduced in NOE to estimate the $F_{\mathrm{W}}$ and $N_{\mathrm{W}}$ functions at a 1-h time step. The WFPS threshold value $\left(\mathrm{WFPS}_{\mathrm{th}}\right)$ was set at 0.7 to trigger denitrification in the NOE model. The PASTIS model revealed that, during the simulation period of 155 days, such moist conditions occurred only $4-6 \mathrm{~h} \mathrm{~d}^{-1}$ on 36 and 34 days for NT and DT systems respectively, and mainly at the end of the day after rainfalls or during the night while field measurements were scheduled in the morning.

\section{3. $\mathrm{N}_{2} \mathrm{O}$ fluxes simulated by $\mathrm{NOE}$}

The daily $\mathrm{N}_{2} \mathrm{O}$ fluxes obtained from frequent and numerous field measurements (Metay et al., 2007b) ranged from 0 to 0.88 and $1.54 \mathrm{~g} \mathrm{Nha}^{-1} \mathrm{~d}^{-1}$ in NT and DT systems respectively (Fig. 3). $\mathrm{N}_{2} \mathrm{O}$ fluxes derived from nitrification in NOE model were in the same order of magnitude, ranging from 0 to 1.46 and to $0.9 \mathrm{~g} \mathrm{~N} \mathrm{ha}^{-1} \mathrm{~d}^{-1}$ in NT and DT systems respectively (Fig. 3) while when denitrification was considered in the model the estimated total $\mathrm{N}_{2} \mathrm{O}$ fluxes reached maximum values of 6.6 and $19.3 \mathrm{~g} \mathrm{~N} \mathrm{ha}^{-1} \mathrm{~d}^{-1}$ in NT and DT systems respectively (Fig. 3 ) that largely exceeded the observed fluxes. Simulation by NOE suggested increases in $\mathrm{N}_{2} \mathrm{O}$ fluxes after rainfall events and fertilizer applications that if occurred were not
Table 5

Cumulative $\mathrm{N}_{2} \mathrm{O}$ fluxes ( $\mathrm{g} \mathrm{Nha}^{-1}$ ) from soil during the cropping season (155 days) estimated from field measurements and from NOE simulations in no-till (NT) and tillage (DT) systems.

\begin{tabular}{lcr}
\hline & \multicolumn{2}{l}{$\mathrm{N}_{2} \mathrm{O}$ fluxes $\left(\mathrm{g} \mathrm{N} \mathrm{ha}^{-1}\right)$} \\
\cline { 3 - 3 } & $\mathrm{NT}$ & $\mathrm{DT}$ \\
\hline Measured & & \\
$\quad$ Total & 9.3 & 13.9 \\
Simulated & & \\
$\quad$ Nit & 88.9 & 47.2 \\
Denit & 123.1 & 84.7 \\
$\quad$ Total (Nit + Denit) & 212.0 & 131.9 \\
\hline
\end{tabular}

well captured by the discrete measurements (Fig. 3). Considering the whole cropping cycle (Table 5), nitrification calculated from NOE simulations accounted for $35 \%$ and $31 \%$ of the total $\mathrm{N}_{2} \mathrm{O}$ fluxes in NT and DT systems respectively.

\section{Discussion}

\subsection{Soil sampling and limits of the approach}

While intact soil cores were preferred in such determination, numerous studies on gas diffusivity and water transport have been based on repacked and structureless soil columns, which suffer from the flaw of not reflecting preferential transport/diffusion through macropores (Allaire et al., 2008). Sieving and breaking the physical mm-scale structure of the soil may effectively decrease the proportion of macropores and using repacked soil cores probably affects the proportion of the effective pore space for gas diffusion and water transport. However, the studied oxisols were well-drained, with a relatively uniform pore structure. These soils develop in subsurface layers a microstructure known as coffee powder (Empresa Brasileira de Pesquisa Agropecuaria, 1984). Although higher than in depth, the structural stability in the surface layer remains low enough to limit the biases due to sieving and repacking the soil cores. Moreover, aggregation larger than $2 \mathrm{~mm}$ in very limited in these soils. Therefore, we hypothesize that the repacking of the uniformly fine-structured soil in this study is not likely to deeply alter transport properties and the gas-exchange occurring within the intact soil cores. Keeping these limitations in mind, we consider that the bias was quite equivalent from a sample to another and that the use of repacked soil allows the comparison between treatments as long as the compaction was restored to the field-observed bulk density for each treatment.

\subsection{Modelling or how to circumvent the limits of discrete measurements}

Instantaneous $\mathrm{N}_{2} \mathrm{O}$ fluxes measured in field using static chambers revealed very low $\mathrm{N}_{2} \mathrm{O}$ fluxes when extrapolated on a daily basis $\left(<1.6 \mathrm{~g} \mathrm{~N} \mathrm{ha}^{-1} \mathrm{~d}^{-1}\right)$. Such low values were reported in other studies on tropical agricultural systems (e.g. Jantilia et al., 2008; Chapuis-Lardy et al., 2009) and are consistent with the conclusions of Yamulki et al. (2001) about the strong diurnal variations in $\mathrm{N}_{2} \mathrm{O}$ fluxes with minimum fluxes generally occurring during the morning. At field scale, soil $\mathrm{N}_{2} \mathrm{O}$ flux is characterized by an extreme spatial and temporal variability that would ideally require continuous monitoring during the year and spatially extensive measurement scheme (Folorunso and Rolston, 1984; Parkin, 1987; Mathieu et al., 2006). For practical and cost reasons, the experimental design is often limited to discrete measurements while resulting data are commonly used for calculating $\mathrm{N}_{2} \mathrm{O}$ budget on larger temporal and spatial scales. Amongst the process-based models proposed to simulate fluctuations in $\mathrm{N}_{2} \mathrm{O}$ fluxes and improve global 
estimates, NOE algorithm considered both nitrification and denitrification as $\mathrm{N}_{2} \mathrm{O}$-emitting pathways (Hénault and Germon, 2000). When nitrification was the only pathway considered in the model, the simulated $\mathrm{N}_{2} \mathrm{O}$ data fitted quite well to the field measurements. When denitrification is triggered, the model suggested $\mathrm{N}_{2} \mathrm{O}$ fluxes which, if really occurred, were poorly captured by discrete in situ measurements. The simulated $\mathrm{N}_{2} \mathrm{O}$ fluxes by both nitrification and denitrification may be considered as low regarding thresholds reported in the literature (Bouwman et al., 2002; Scheer et al., 2008). Divergence in $\mathrm{N}_{2} \mathrm{O}$ flux levels between measurements and simulations may be caused either by inadequate field measurements (sampling time in particular) or by uncertainties of the modelling approach.

\subsection{WFPS: a key factor to simulate $\mathrm{N}_{2} \mathrm{O}$ fluxes}

The soil water content has a complex effect on $\mathrm{N}_{2} \mathrm{O}$-emitting pathways by controlling aeration, diffusion of substrate and microbial activity while WFPS is commonly considered as a determining factor in $\mathrm{N}_{2} \mathrm{O}$ flux. Davidson (1991) suggests that $\mathrm{N}_{2} \mathrm{O}$ fluxes by nitrification occur between 30 and 70\% WFPS with a maximum at $50 \%$, whereas $\mathrm{N}_{2} \mathrm{O}$ fluxes by denitrification occur between 50 and $90 \%$ WFPS with a maximum at $70 \%$. In addition, according to Davidson (1991) $\mathrm{N}_{2}$ starts being emitted at 70\% WFPS and is the main product of $\mathrm{N}$ gas emissions when soil moisture exceeds $75 \%$ WFPS. The main point of discussion concerning the validity of the water function $F_{\mathrm{W}}$ in various simulations in NOE model performed by Hénault et al. (2005) dealt with the WFPS threshold $\left(\mathrm{WFPS}_{\text {th }}\right)$ for an existing denitrification activity. These authors set $62 \%$ WFPS as the threshold default value in their model developed for medium-textured temperate soils. They also suggested that it could vary with soil texture and therefore be clearly site-specific. Heinen (2006) also showed that denitrification was highly sensitive to the WFPS threshold triggering denitrification, and that this parameter was dependent on soil type. The exponential form of the $F_{\mathrm{W}}$ induces a large variation of denitrification rate for a small variation in the soil water filled pore space. This implies that the $\mathrm{WFPS}_{\text {th }}$ requires precise definition. Laboratory experiments showed that $70 \%$ WFPS was a clear trigger point for the production of $\mathrm{N}_{2} \mathrm{O}$ by denitrification in our soils which was in good agreement with results from Hergoualc'h et al. (2007) for a tropical soil under coffee agroforestry plantation in Costa Rica. Such a value was also in the range extracted from a literature review by Lehuger et al. (2009). Thus, this value was used in place of the default model's threshold of $62 \%$ WFPS in our NOE simulation. We simulated soil water content at 1-h time step during the whole cropping period using PASTIS model parameterized with site-specific hydraulic properties. It provided a satisfactory estimation of water content dynamics in the soil profile. Simulated volumetric water content showed several peaks, some of which corresponded to WFPS up to $80 \%$ for NT and $83 \%$ for DT, respectively. While soil water contents were rarely high enough to favor $\mathrm{N}_{2} \mathrm{O}$ production by denitrification ( 36 and 34 events for NT and DT respectively out of 155 days), these "denitrifying" conditions generally occurred at the end of the day or during the night. As field measurements were realized on each occasion during the morning, $\mathrm{N}_{2} \mathrm{O}$ potentially emitted during these time-periods was systematically not captured by the discrete measurements and not taken into account in the calculation of $\mathrm{N}_{2} \mathrm{O}$ fluxes on a daily basis by extrapolation of field measured data.

\subsection{Laboratory determination of $\mathrm{N}_{2} \mathrm{O}$ potential of emissions to calibrate the model}

We also tried to minimise uncertainties due to the modelling approach by an efficient and site-specific parameterization which was determined in laboratory experiments. According to Garrido et al. (2002), nitrification rates estimations are based on the study of $\mathrm{NO}_{3}{ }^{-}$production in non-limiting $\mathrm{NH}_{4}{ }^{+}$conditions for various WFPS. In our study, maximum nitrification rate was obtained for a WFPS close to $45 \%$ while Linn and Doran (1984) found that nitrification occurred for WFPS ranging between 10 and $80 \%$ with a maximum at $60 \%$. Potentials of nitrification were significantly higher for NT than for DT (2.16 vs. $0.92 \mathrm{mg} \mathrm{N} \mathrm{kg}^{-1} \mathrm{~d}^{-1}$ ). While mineral N was larger in NT than in DT soils microbial biomass was probably more active under systems NT than under DT (Rabary et al., 2008; Sparrow et al., 2006). De Boer and Kowalchuk (2001) proposed that autotrophic nitrification was possibly restricted to $\mathrm{pH}$-neutral micro-sites in acid soils. While these values were lower than those reported by Hergoualc'h et al., 2009 for Costa-Rican soils or by Garrido et al. (2002) for temperate soils, it was in good agreement with the low $\mathrm{N}_{2} \mathrm{O}$ fluxes simulated by nitrification or measured in the field. The proportion of nitrified $\mathrm{N}$ emitted as $\mathrm{N}_{2} \mathrm{O}$ were lower than the range of $0.5-0.9 \%$ reported by Hénault et al. (2005) for temperate soils or by Hergoualc'h et al., 2009 for tropical soils in Costa-Rica. The potential denitrification rate $\left(D_{\mathrm{P}}\right)$ was similar in both treatments (NT vs. DT), circa $1 \mathrm{~kg} \mathrm{~N} \mathrm{ha}^{-1} \mathrm{~d}^{-1}$. Low values were also observed in soils from other tropical agricultural systems, such as in Puerto Rico (Hénault et al., 2005), Costa-Rica (Hergoualc'h et al., 2009) and Madagascar (Chapuis-Lardy et al., 2009) while temperate soils commonly exhibited potentials larger than $5 \mathrm{~kg} \mathrm{Nha}^{-1} \mathrm{~d}^{-1}$ (Hénault and Germon, 2000). In a literature review, Barton et al. (1999) reported that in $85 \%$ of the cultivated soils they examined denitrification potentials were higher than $1 \mathrm{~kg}$ $\mathrm{Nha}^{-1} \mathrm{yr}^{-1}$, with an average value of $13 \mathrm{~kg} \mathrm{~N} \mathrm{ha}^{-1} \mathrm{yr}^{-1}$. As availability of organic labile compounds is a key factor in denitrification (e.g. Williams et al., 1999; Granli and Bøckman, 1994), the low C contents in our soils may limit microbial activity and explain these low rates. Soil acidity and probable P deficiency as commonly observed in Brazilian Oxisols (Chapuis-Lardy et al., 2002) may also impact soil microbial processes. These physiochemical conditions were implicitly taken into account by the virtue of the site-specificity of the model parameterization. The proportion of denitrified $\mathrm{N}$ emitted as $\mathrm{N}_{2} \mathrm{O}\left(r_{\max }\right)$ showed that $\mathrm{N}_{2} \mathrm{O}$ can be reduced to $\mathrm{N}_{2}$ in the studied soils while elsewhere in more acidic soils this capacity was limited (Hénault et al., 2001; Hergoualc'h et al., 2009). Potential key controls such as structure and activity of denitrifying communities still require further investigations (Baudoin et al., 2009). This capacity along with limited denitrification potentials may explain the weakness of simulated $\mathrm{N}_{2} \mathrm{O}$ fluxes which can be considered as low regarding literature reports (Bouwman et al., 2002; Scheer et al., 2008).

\subsection{Specificity and heterogeneity of the soil to produce $\mathrm{N}_{2} \mathrm{O}$}

The relationship between the nitrification and denitrification rates and the $\mathrm{N}_{2} \mathrm{O}$ evolution in soil is not straightforward, and the contribution of both pathways to $\mathrm{N}_{2} \mathrm{O}$ fluxes is highly dependent on soil conditions such as availability of a mineral $\mathrm{N}$ source (substrate for nitrification or denitrification), and on soil temperature, soil water content, and (for denitrification) the availability of labile organic compounds (e.g. Granli and Bøckman, 1994; Skiba and Smith, 2000). These observations underlined the importance of site-specificity in NOE model parameterization. Nitrification and denitrification processes may occur simultaneously in different microsites of the same soil (Stevens et al., 1997) but there is often uncertainty associated with which process is predominantly contributing to emissions from a particular soil. Nitrification is a relatively constant process in soils, whereas denitrification acts with high time and space fluctuations. Nitrification is the predominant process contributing to $\mathrm{N}_{2} \mathrm{O}$ fluxes at WFPS from 35 to $60 \%$ (Bateman and Baggs, 2005; Gilliam et al., 2010). At higher water contents, $\mathrm{N}_{2} \mathrm{O}$ fluxes are much greater in magnitude and are associ- 
ated primarily with the denitrification process (Bateman and Baggs, 2005). As various studies underlined high denitrification activity in 'hot spots' created by decomposing organic matter which generated anaerobic microsites, our simulation revealed larger $\mathrm{N}_{2} \mathrm{O}$ fluxes in no-till situations with mulch at the soil surface (NT) than under tillage treatment (DT). Considering the whole cropping season, the relative proportion of nitrification calculated from NOE simulations accounted for 35 and 31\% for NT and DT, respectively (data not shown). These results confirmed those obtained by Hénault et al. (2005) from simulation in Puerto Rico soils and by Hergoualc'h et al. (2007) in Costa Rica soils. The use of urea as N-fertilizer in our soils may explain the contribution level of nitrification to $\mathrm{N}_{2} \mathrm{O}$ flux (Bremmer, 1997).

\section{Conclusions}

The approach we proposed in this study, which consisted in continuous simulations of WFPS using the water transfer model PASTIS to implement the NOE model and simulate the $\mathrm{N}_{2} \mathrm{O}$ fluxes derived from both denitrification and nitrification pathways brought complementary information to field approach and potentially improved assessment of $\mathrm{N}_{2} \mathrm{O}$ budget. As the studied soil is well-aerated, this result is in agreement with the conclusions of Rochette (2008) who stated that $\mathrm{N}_{2} \mathrm{O}$ fluxes only counterbalance no-till positive effects on carbon sequestration (Metay et al., 2007a) in case of poorly-finetextured agricultural soils in regions with a humid climate. Further studies, especially in case of soils with a well-marked structural profile should address these specific methodological points by (i) using intact soil cores to prevent errors in estimating nitrification and denitrification potentials (Booth et al., 2006); (ii) testing the interest in having vertical soil sampling design to parameterize the model and better estimating the gas emissions occurring at soil surface and (iii) considering both the spatial heterogeneity of soil and the chambers position on the field prior to sampling soil cores for laboratory determination. It would also be interesting to look further into such approaches to improve data sets on $\mathrm{N}_{2} \mathrm{O}$ fluxes under tropics with specific attention paid to soil water content estimation in these soils and its consequences on $\mathrm{N}_{2} \mathrm{O}$ fluxes. In particular, the reasons for such low $\mathrm{N}_{2} \mathrm{O}$ fluxes, the possible soil sink for $\mathrm{N}_{2} \mathrm{O}$ (Chapuis-Lardy et al., 2007) and the consequences of straw mulch on a possible reduction of greenhouse gas emissions (Xu et al., 2003) are to be investigated. Further research efforts should also address validations of model and the potential development of a "tropical version" of NOE (Hénault et al., 2005; Hergoualc'h et al., 2009) that integrates the specificity of $\mathrm{N}$ cycle and soil organic matter decomposition under tropical climate (Abbadie and Lensi, 1990; Six et al., 2002).

\section{Acknowledgments}

This work was completed thanks to the grant given to Aurélie Metay by the French Ministry of Research and Technologies. A financial support was brought by the FFEM (Fonds Français pour l'Environnement Mondial). Project CZZ1224.02X "Bilan comparé des émissions/séquestration des gaz à effet de serre dans les systèmes de culture agro-écologiques (semis direct sous couverture végétale) et les systèmes de culture traditionnels. Le cas du Brésil" and CIRAD (financial support from the CIRAD scientific direction). We would like to thank the persons who had helped to complete the laboratory analysis at CENA, CIRAD, and CEFE research centers. The authors also thank the anonymous reviewers for the helpful comments and suggestions provided.

\section{References}

Abbadie, L., Lensi, R., 1990. Carbon and nitrogen mineralization and denitrification in a humid savanna of West Africa (Lamto, Côte d'Ivoire). Acta Oecol. 11, 717-728.

Allaire, S.E., Lafond, J.A., Cabral, A.R., Lange, S.F., 2008. Measurement of gas diffusion through soils: comparison of laboratory methods. J. Environ. Monit. 10, 1326-1336.

Baggs, E.M., Stevenson, M., Pihlatie, M., Regar, A., Cook, H., Cadisch, G., 2003. Nitrous oxide emissions following application of residues and fertiliser under zero and conventional tillage. Plant Soil 254, 361-370.

Bandibas, J., Vermoesen, A., de Groot, C.J., Van Cleemput, O., 1994. The effect of different moisture regimes and soil characteristics on nitrous oxide emission and consumption by different soils. Soil Sci. 158, 106-114.

Barton, L., McLay, C.D.A., Schipper, L.A., Smith, C.T., 1999. Annual denitrification rates in agricultural and forest soils: a review. Aust. J. Soil Res. 37, 1073-1093.

Bateman, E.J., Baggs, E.M., 2005. Contributions of nitrification and denitrification to $\mathrm{N}_{2} \mathrm{O}$ emissions from soils at different water-filled pore space. Biol. Fertil. Soils 41, 379-388

Baudoin, E., Philippot, L., Cheneby, D., Chapuis-Lardy, L., Fromin, N., Bru, D., Rabary B., Brauman, A., 2009. Direct seeding mulchbased cropping increases both the activity and the abundance of denitrifier communities in a tropical soil. Soil Biol. Biochem. 41, 1703-1709.

Bernoux, M., Cerri, C.C., Cerri, C.E.P., Siqueira Neto, M., Metay, A., Perrin, A.S., Scopel, E., Razafimbelo, T., Blavet, D., Piccolo, M.C., Pavei, M., Milne, E., 2006. Cropping systems, carbon sequestration and erosion in Brazil, a review. Agron. Sustain. Dev. 26, 1-8.

Booth, M.S., Stark, J.M., Hart, S.C., 2006. Soil-mixing effects on inorganic nitrogen production and consumption in forest and shrubland soils. Plant Soil 289 5-15.

Bouwman, A.F., Boumans, L.J.M., Batjes, N.H., 2002. Emissions of $\mathrm{N}_{2} \mathrm{O}$ and NO from fertilized fields. Summary of available measurement data. Global Biogeochem. Cycl. 16, 1058-1070.

Bremmer, J.M., 1997. Sources of nitrous oxide in soils. Nutr. Cycl. Agroecosyst. 49, 7-16.

Cannavo, P., Recous, S., Parnaudeau, V., Reau, R., 2008. Modelling N dynamics to assess environmental impacts of cropped soils. Adv. Agron. 97, 131-174.

Castro Fo, C., Logan, T.J., 1991. Liming effects on the stability and erodibility of some Brazilian oxisols. Soil Sci. Soc. Am. J. 55, 1407-1413.

Chapuis-Lardy, L., Wrage, N., Metay, A., Chotte, J.-L., Bernoux, M., 2007. Soils, a sink for $\mathrm{N}_{2} \mathrm{O}$ ? A review. Global Change Biol. 13, 1-17.

Chapuis-Lardy, L., Metay, A., Martinet, M., Rabenarivo, M., Toucet, J., Douzet, J.M., Razafimbelo, T., Rabeharisoa, L., Rakotoarisoa, J., 2009. Nitrous oxide fluxes from Malagasy agricultural soils. Geoderma 148, 421-427.

Chapuis-Lardy, L., Brossard, M., Lopes Assad, M.L., Laurent, J.-Y., 2002. Carbon and phosphorus stocks of clayey Ferralsols in Cerrado native and agroecosystems, Brazil. Agric. Ecosyst. Environ. 92, 147-158.

Chen, D., Li, Y., Grace, P., Mosier, A., 2008. $\mathrm{N}_{2} \mathrm{O}$ emissions from agricultural lands: a synthesis of simulation approaches. Plant Soil 309, 169-189.

Crutzen, P.J., 1981. Atmospheric chemical processes of the oxides of nitrogen including nitrous oxide. In: Delwiche, C.C. (Ed.), Denitrification, Nitrification and Atmospheric Nitrous Oxide. John Wiley and Sons, New York, pp. 17-44.

Davidson, E.A., 1991. Fluxes of nitrous oxide and nitric oxide from terrestrial ecosysts. In: Roger, J.E., Whitman, W.B. (Eds.), Microbial Production and Consumption of Greenhouse Gases: Methane, Nitrogen Oxides and Halomethanes. American Society for MicroBiol, Washington, DC, pp. 219-235.

Davidson, E.A., Matson, P.A., Brooks, P.D., 1996. Nitrous oxide emission controls and inorganic nitrogen dynamics in fertilized tropical agricultural soils. Soil Sci. Soc. Am. J. 60, 1145-1152.

De Boer, W., Kowalchuk, G.A., 2001. Nitrification in acid soils: microorganisms and mechanisms. Soil Biol. Biochem. 33, 853-866.

Dick, J., Skiba, U., Wilson, J., 2001. The effect of rainfall on $\mathrm{NO}$ and $\mathrm{N}_{2} \mathrm{O}$ emissions from Ugandan agroforest soils. Phyton: Ann. Rei Bot. A 41, 73-80.

Dobbie, K.E., Smith, K.A., 2003. Nitrous oxide emission factors for agricultural soils in Great Britain: the impact of soil water-filled pore space and other controlling variables. Global Change Biol. 9, 204-218.

Embrapa, 1984. Serviço Nacional de Levantamento e Conservação de Solos. Levantamento de reconhecimento dos solos do estado do Paraná. Londrina: EMBRAPA-SNLCS/SUDESUL/IAPAR, 1/2: 791.

Findeling, A., 2001. Etude et modélisation de certains effets du semis direct avec paillis de résidus sur les bilans hydrique, thermique et azoté d'une culture de maïs pluvial au Mexique. Dissertation. Ecole Nationale du Génie Rural des Eaux et Forêts de Montpellier.

Folorunso, O.A., Rolston, D.E., 1984. Spatial variability of field measured denitrification gas fluxes. Soil Sci. Soc. Am. J. 48, 1214-1219.

Freney, J.R., Denmead, O.T., Simpson, J.R., 1978. Soil as a source or sink for atmospheric nitrous oxide. Nature $273,530-532$.

Garrido, F., Hénault, C., Gaillard, H., Pérez, S., Germon, J.C., 2002. $\mathrm{N}_{2} \mathrm{O}$ and NO emissions by agricultural soils with low hydraulic potentials. Soil Biol. Biochem. 34 559-575.

Gilliam, F.S., Cook, A., Lyter, S., 2010. Effects of experimental freezing on soil nitrogen (N) dynamics in soils of a net nitrification gradient in an N-saturated hardwood forest ecosystem. Can. J. Forest Res. 40, 436-444.

Granli, T., Bøckman, O.C., 1994. Nitrous oxide from agriculture. Norw. J. Agric. Sci. Suppl. 12, 1-128.

Heinen, M., 2006. Simplified denitrification models: overview and properties. Geoderma 133, 444-463. 
Hénault, C., Bizouard, F., Laville, P., Gabrielle, B., Nicoullaud, B., Germon, J.C., Cellier, P., 2005. Predicting in situ soil $\mathrm{N}_{2} \mathrm{O}$ emission using NOE algorithm and soil database. Global Change Biol. 11, 115-127.

Hénault, C., Chèneby, D. Heurlier, K., Garrido, F., Perez, S., Germon, J.C., 2001. Laboratory kinetics of soil denitrification are useful to discriminate soils with potentially high levels of $\mathrm{N}_{2} \mathrm{O}$ emission on the field scale. Agronomie 21, 713-723.

Hénault, C., Germon, J.C., 2000. NEMIS, a predictive model of denitrification on the field scale. Eur. J. Soil Sci. 51, 257-270.

Hergoualc'h, K., Harmand, J.M., Cannavo, P., Skiba, U., Oliver, R., Hénault, C., 2009. The utility of process-based models for simulating $\mathrm{N}_{2} \mathrm{O}$ emissions from soils: a case study based on Costa Rican coffee plantations. Soil Biol. Biochem. 41, 2343-2355.

Hergoualc'h, K., Skiba, U., Harmand, J.M., Oliver, R., 2007. Processes responsible for the nitrous oxide emission from a Costa Rican Andosol under a coffee agroforestry plantation. Biol. Fertil. Soils 43, 787-795.

IPCC, 2007. Climate Change 2007: Mitigation of Climate Change: Contribution of Working Group III to the Intergovernmental Panel on Climate Change Fourth Assessment Report. Cambridge University Press, Cambridge.

Jantilia, C.P., dos Santos, H.P., Urquiaga, S., Boddey, R.M., Alves, B.J.R., 2008. Fluxes of nitrous oxide from soil under different crop rotations and tillage systems in the south of Brazil. Nutr. Cycl. Agroecosyst. 10, 161-173.

Lafolie, F., 1991. Modelling water flow, nitrogen transport end root uptake including physical non-equilibrium and optimization of the root water potential. Fertil. Res. 27, 215-231.

Lehuger, S., Gabrielle, B., van Oijen, M., Makowski, D., Germon, J.C., Morvan, T., Hénault, C., 2009. Bayesian calibration of the nitrous oxide emission module of an agro-ecosystem model. Agric. Ecosyst. Environ. 133, 208-222.

Linn, D., Doran, J.W., 1984. Effect of water-filled pore space on carbon dioxide and nitrous oxide production in tilled and non tilled soils. Soil Sci. Soc. Am. J. 48, 1267-1272.

Mathieu, O., Lévêque, J., Hénault, C., Milloux, M.-J., Bizouard, F., Andreux, F., 2006. Emissions and spatial variability of $\mathrm{N}_{2} \mathrm{O}, \mathrm{N}_{2}$ and nitrous oxide mole fraction at the field scale, revealed with $15 \mathrm{~N}$ isotopic techniques. Soil Biol. Biochem. 38, 941-951.

Metay, A., Alves Moreira, J.A., Bernoux, M., Boyer, T., Douzet, J.M., Feigl, B., Feller, C., Maraux, F., Oliver, R., Scopel, E., 2007a. Storage and forms of organic carbon in a no-tillage under cover crops system on clayey oxisol in dryland rice production (Cerrados, Brazil). Soil Till. Res. 94, 122-132.

Metay, A., Oliver, R., Scopel, E., Douzet, J.M., Alves Moreira, J.A., Maraux, F., Feigl, B.J., Feller, C., 2007b. $\mathrm{N}_{2} \mathrm{O}$ and $\mathrm{CH}_{4}$ emissions from soils under conventional and no-till management practices in Goiânia (Cerrados, Brazil). Geoderma 141, 78-88.

Mosier, A., Kroeze, C., Nevison, C., Oenema, O., Seitzinger, S., van Cleemput, O., 1998. Closing the global $\mathrm{N}_{2} \mathrm{O}$ budget: nitrous oxide emissions through the agricultural nitrogen cycle. Nutr. Cycl. Agroecosyst. 52, 225-248.

Mulvaney, R.L., 1996. Nitrogen inorganic forms. In: Sparks, D.L. (Ed.), Methods of Soil Analysis. Part 3: Chemical Methods. , third ed. SSSA and ASA, Madison, WI, USA, pp. 1123-1131.

Nash, J.E., Sutcliffe, J.V., 1970. River flow forecasting through conceptual models, part I-a discussion of principles. J. Hydrol. 10, 282-290.

Parkin, T.B., 2008. Effect of sampling frequency on estimates of cumulative nitrous oxide emissions. J. Environ. Qual. 37, 1390-1395.
Parkin, T.B., 1987. Soil microsites as a source of denitrification variability. Soil Sci. Soc. Am. J. 51, 1194-1199.

Rabary, B., Sall, S., Letourmy, P., Husson, O., Ralambofetra, E., Moussa, N., Chotte, J.-L., 2008. Effects of living s or residue amendments on soil microbial properties in direct seeded cropping systems of Madagascar. Appl. Soil Ecol. 39, 236-243.

Reyes, V., 2002. Quantification et modélisation des flux hydriques, thermiques et azotés dans les systèmes de culture en semis direct avec couverture végétale dans la région des Cerrados brésiliens. Dissertation. Université Montpellier II Sciences et Techniques du Languedoc, France.

Robertson, G.P., Tiedje, J.M., 1987. Nitrous oxide sources in aerobic soils: nitrification, denitrification and other biological processes. Soil Biol. Biochem. 19, 187-193.

Rochette, P., 2008. No-till only increases $\mathrm{N}_{2} \mathrm{O}$ emissions in poorly-aerated soils. Soil Till. Res. 101, 97-100.

Scheer, C., Wassmann, R., Kienzler, K., Ibragimov, N., Eschanov, R., 2008. Nitrous oxide emissions from fertilized, irrigated cotton (Gossypium hirsutum L.) in the Aral Sea Basin, Uzbekistan: influence of nitrogen applications and irrigation practices. Soil Biol. Biochem. 40, 290-301.

Six, J., Feller, C., Denef, K., Ogle, S.M., Sa, J.C.M., Albrecht, A., 2002. Soil organic matter, biota and aggregation in temperate and tropical soils: effect of no-tillage. Agronomie 22, 755-775.

Skiba, U., Smith, K.A., 2000. The control of nitrous oxide emissions from agricultural and natural soils. Chemosphere: Global Change Sci. 2, 379-386.

Smith, K.A., Ball, T., Conen, F., Dobbie, K.E., Massheder, J., Rey, A., 2003. Exchange of greenhouse gases between soil and atmosphere: interaction of soil physical factors and biological processes. Eur. J. Soil Sci. 54, 779-791.

Soil Survey Staff, Agriculture Handbook Number 436 1999. Soil Taxonomy. A Basic System of Soil Classification for Making and Interpreting Soil Surveys. United States Department of Agriculture - Natural Resources Conservation Service.

Sparrow, S.D., Lewis, C.E., Knight, C.W., 2006. Soil quality response to tillage and crop residue removal under subarctic conditions. Soil Till. Res. 91, 15-21.

Stehfest, E., Bouwman, L., 2006. $\mathrm{N}_{2} \mathrm{O}$ and NO emission from agricultural fields and soils under natural vegetation: summarizing available measurement data and modelling of global annual emissions. Nutr. Cycl. Agroecosyst. 74, 207-228.

Stevens, R.J., Laughlin, R.J., Burns, L.C., Arah, J.R.M., Hood, R.C., 1997. Measuring the contributions of nitrification and denitrification to the flux of nitrous oxide from soil. Soil Biol. Biochem. 29, 139-151.

Van den Berg, M., Klamt, E., Van Reeuwijk, L.P., Sombroek, W.G., 1997. Pedotransfer functions for the estimation of moisture retention characteristics of ferralsols and related soils. Geoderma 78, 161-180.

Williams, D.L., Ineson, P., Coward, P.A., 1999. Temporal variations in nitrous oxide fluxes from urine-affected grassland. Soil Biol. Biochem. 31, 779-788.

Xu, Y.C., Shen, Q.R., Li, M.L., Dittert, K., Sattelmacher, B., 2003. Effect of soil water status and mulching on $\mathrm{N}_{2} \mathrm{O}$ and $\mathrm{CH}_{4}$ emission from lowland rice field in China. Biol. Fertil. Soils 39, 215-217.

Yamulki, S., Toyoda, S., Yoshida, N., Veldkamp, E., Grant, B., Bol, R., 2001. Diurnal fluxes and the isotopomer ratios of $\mathrm{N}_{2} \mathrm{O}$ in a temperate grassland following urine amendment. Rapid Commun. Mass Spectrom. 15, 1263-1269.

Yanai, J., Sawamoto, T., Oe, T., Kanako, K., Yamakawa, K., Sakamoto, K., Naganawa, T., Inubushi, K., Hatano, R., Kosaki, T., 2003. Spatial variability of nitrous oxide emissions and their soil-related determining factors in an agricultural field. J. Environ. Qual. 32, 1965-1977. 